\title{
PROBLEMATIKA PENDIDIK DAN PESERTA DIDIK TERHADAP PELAJARAN MATEMATIKA
}

\author{
Leili Sholihatunnisa' $^{1}$, M. Imam Darmawansyah ${ }^{2}$, Noviani Sa' adah $^{3}$, Wati Susilawati ${ }^{4}$ \\ ${ }^{1}$ UIN Sunan Gunung Djati Bandung \\ Leilisn98@gmail.com \\ ${ }^{2}$ UIN Sunan Gunung Djati Bandung \\ mimamdarmawansyah@gmail.com \\ ${ }^{3}$ UIN Sunan Gunung Djati Bandung \\ novianisaadahopi@gmail.com \\ ${ }^{4}$ UIN Sunan Gunung Djati Bandung \\ Wati85@uinsgd.ac.id
}

\begin{abstract}
ABSTRAK
Salah satu hakikat belajar adalah terjadinya sebuah perubahan. Proses pembelajaran terjadi dalam kehidupan sehari-hari. Pembelajaran matematika merupakan salah satu pusat perhatian di dunia pendidikan, yang menjadi fokus utama adalah prolematika yang muncul dilapangan, yakni problematika pada kompetensi pendidik dan menurunnya kualitas proses dan hasil belajar peserta didik pada pelajaran matematika. Sehingga tujuan penulisan ini untuk mengetahui solusi dari problematika pendidik dan peserta didik pada pelajaran matematika.
\end{abstract}

Kata Kunci: matematika, problematika, solusi.

\section{PENDAHULUAN}

Dewasa ini pengembangan profesi pendidik sudah menjadi tuntutan yang tidak bisa ditawar lagi. Baik secara legal formal maupun secara normatif, Pengembangan profesi pendidik sudah mencapai tahap sistemik. Serangkaian masalah yang meliputi dunia kependidikan dewasa ini masih perlu mendapat perhatian dari semua pihak. Mulai dari kualitas tenaga pendidik yang belum mencapai target hingga masalah kesejahteraan pendidik.

Fakta di lapangan, permasalahan jauh lebih kompleks dalam lingkungan pendidikan kita. Boleh dikatakan tingkat kualitas dan kompetensi pendidik menjadi kendala utamanya, mulai dari pendidik yang tidak memiliki kelayakan kompetensi untuk mengajar mata pelajaran tertentu khususnya pelajaran matematika, hingga rendahnya tingkat profesionalisme pendidik itu sendiri.

Dahin (2002: 23); (Muhammad Nurtanto: 2016) menyatakan bahwa, orang yang profesional memiliki sikap-sikap yang berbeda dengan orang yang tidak profesional meskipun 
dalam pekerjaan yang sama atau katakanlah berada pada satu ruang kerja. Sikap profesional dan kompetensi keahlian yang dimiliki pendidik tidak lain pada bidang pembelajaran khususnya pelajaran matematika. Pendidik merupakan komponen utama dalam proses pembelajaran di sekolah yang menentukan keberhasilan peserta didiknya. Barghava et al. (2011:77); (Muhammad Nurtanto: 2016) menyatakan bahwa faktor terpenting dalam pembelajaran adalah pendidik.

Pendidik saat ini dituntut bukan hanya sekadar melaksanakan pekerjaan datangmengajar lalu pulang. Tapi ia dituntut untuk mencapai serangkaian kualifikasi dalam pencapaian mutu profesionalisme yang telah ditetapkan. Pendidik bukan hanya dituntut perlu memiliki ilmu pengetahuan dan keterampilan mengajar, tetapi juga harus memiliki keprofesionalan. Upaya meningkatkan kualitas hasil pendidikan sangat tergantung dari kemampuan pendidik untuk mengembangkan kreativitasnya itu. Lalu bagaimana mengmbangkan profesionalitas pendidik?

Selain itu, banyak problematika yang muncul dari peserta didik yang menjadi pusat perhatian pendidikan pada pelajaran matematika. Hudojo (1999); (Hasratuddin: 2008) mengatakan bahwa pembelajaran matematika sekolah mulai dari SD sampai berpendidikan tinggi merupakan permasalahan yang tak kunjung terselesaikan. Pernyataan tersebut membuktikan rendahnya prestasi bidang studi matematika dibandingkan dengan bidang studi lainnya.

Hasil penelitian Soedjadi (2001); (Hasratuddin: 2008) menunjukkan bahwa daya serap rata rata peserta didik SLTP untuk pelajaran matematika tergolong rendah hanya $42 \%$. Selanjutnya Hudojo (1998); (Hasratuddin: 2008) mengatakan dalam hasil temuannya bahwa banyak tamatan SMU tidak terampil dalam soal aritmatik walaupun sederhana dan mereka tetap gagal belajar keterampilan tersebut, dan kegagalan itu diulang lagi di tingkat SLTA. Dari Problematika tersebut, bagaimana meningkatkan kualitas proses dan hasil belajar peserta didik pada pelajaran matematika?

\section{Rendahnya Kualitas Kompetensi Profesionalisme, Pedagogik, Kepribadian, Dan Sosial Pendidik Matematika}

Pendidik dalam proses pendidikan di sekolah memliki peran sebagai pengajar dan pendidik. Sebagai pengajar, bertugas memberikan bahan pelajaran ke peserta didik. Sedangkan sebagai pendidik, bertugas membimbing dan membina agar menjadi manusia yang 
cakap, aktif, dan kreatif mandiri dan inovatif, sebagai tenaga pendidik dan mempunyai tugas dan tanggungjawab menjadi tenaga professional.

Rendahnya kompetensi pendidik yang menjadi salah satu penyebabnya adalah karena mata pelajaran yang diampunya tidak sesuai dengan latar belakang pendidikannya, mengajarkan mata pelajaran yang bukan pada bidang keahliannya, tidak dapat menyampaikan materi pembelajaran dengan baik.

Secara sederhana, pendidik diartikan sebagai seorang yang pekerjaannya adalah mengajar. Dalam undang-undang pendidik (pasal 1 ayat 1) dinyatakan bahwa pendidik adalah pendidik profesional dengan tugas utama mendidik, mengajar, membimbing, mengarahkan, melatih, dan mengevaluasi peserta didik pada pendidikan anak usia dini, jalur formal, pendidikan dasar, dan menengah atas.

Michael Zwell dalam Wibowo (2010:339) mengungkapkan bahwa terdapat beberapa faktor yang dapat mempengaruhi kecakapan kompetensi seseorang, yaitu sebagai berikut:

a. Keyakinan dan nilai-nilai

b. Keterampilan

c. Pengelaman

d. Karakteristik kepribadian

e. Motivasi

f. Isu emosional

g. Kemampuan intelektual

h. Budaya organisasi.

Dalam undang-undang nomor 14 tahun 2005 tentang pendidik dan dosen pasal 1 ayat 10, disebutkan "kompetensi adalah seperangkat pengetahuan keterampilan dan prilaku ynag harus dimiliki, dihayati, dan dikuasai oleh pendidik atau dosen dalam melaksanakan tugas keprofesionalan". Sedangkan pasal 10 ayat 1 dinyatakan "kompetensi pendidik sebagai agen pembelajaran pada jenjang pendidikan dasar menengah serta pendidikan anak usia dini meliputi
a. Kompetensi pedagogik
b. Kompetensi kepribadian
c. Kompetensi professional
d. Kompetensi sosial. 
Kompetensi pedagogik merupakan kemampuan pendidik dalam pengelolaan pembelajaran peserta didik dengan berbasis pendekatan yang bersifat mendidik, sehingga melaksanakan fungsi profesionalnya dengan lebih efektif (Indriani: 2015). Peraturan menteri pendidikan nasional no 16 tahun 2007 tentang standar kualifikasi dan kompetensi pendidik telah menggaris bawahi 10 kompetensi pedagogis sebagai berikut:

a. Menguasai karakteristik peserta didik dari aspek fisik, moral, cultural, emosional, dan intelektual

b. Menguasai teori-teori belajar dan prinsip-prinsip pembelajaran yang mendidik.

c. Mengambangkan kurukulum yang terkait dengan mata pelajaran atau pengembangan yang diampu.

d. Menyelenggarakan pembelajaran yang mendidik.

e. Memanfaatkan teknologi informasi dan komunikasi untuk kepentingan pembelajaran.

f. Memfasilitasi pengembangan potensi peserta didik untuk mengaktualisasikan berbagai kompetensi yang dimilikinya.

g. Berkomunikasi secara efektif, empatik, dan santun dengan peserrta didik.

h. Menyelenggarakan penilaian dan evaluasi proses dan hasil belajar.

i. Memanfaatkan hasil penilaian dan evaluasi untuk kepentingan pembelajaran.

j. Melakukan tindakan reflektif untuk peningkatan kualitas pembelajaran.

Tidak sedikit problematika yang timbul pada pendidikan karena rendahnya kompetensi pedagogik pada pendidiknya seperti tidak menguasai teori-teori belajar dan prinsip-prinsip pembelajaran, tidak mau dan takut dalam mengembangkan kurikulum, padahal yang sangat diinginkan peserta didik adalah pendidik yang inovatif, kreatif dan menyenangkan.

Selain kompetensi pedagogik, yang menjadi perbincangan adalah kompetensi professional. Kompetensi profesional yaitu kemampuan yang harus dimiliki pendidik dalam perencanaan dan pelaksanaan proses pembalajaran. Pendidik yang profesional diyakini mampu memotivasi peserta didik untuk mengoptimalkan potensinya dalam upaya pencapaian standar pendidikan yang ditetapkan. Dari profesinalismenya tersebut muncul sebuah tanggungjawab besar, yakni menyiapkan manusia yang berkualitas yang tidak tegerus oleh majunya zaman.

Sapan, dkk (2017:91) menyatakan bahwa tingkat keprofesionalan seorang pendidik dapat dilihat dari kompetensi sebagai berikut: 
a. Kemampuan untuk menguasai landasan pendidikan, misalnya paham akan tujuan pendidikan yag harus dicapai baik tujuan nasional, institusional, kulikuler, dan tujuan pembelajaran.

b. Pemahaman dalam bidang psikologi pendidikan, misalnya paham tentang tahapan perkembangan peserta didik, paham tentang teori-teori belajar.

c. Kemampuan dalam penguasaan materi pembelajaran sesuai dengan bidang studi yang diiajarkan.

d. Kemampuan dalam mengaplikasikan berbagai metodologi dan strategi pembelajaran.

e. Kemampuan merancang dan memanfaatkan berbagaai media dan sumber belajar.

f. Kemampuan dalam melaksanakan evaluasi pembelajaran

g. Kemampuan dalam menyusun program

h. Kemampuan dalam mellaksanakan unsur penunjang, misalnya administrasi sekolah, bimbingan, dan penyuluhan.

i. Kemampuan dalam melaksanakan penelitian dan berfikir ilmiah untuk meningkatkan kinerja.

Tingkat keprofesionalan seorang pendidik menjadi hal penting karena banyak masalah pendidikan yang disebabkkan oleh faktor kepribadian pendidik yang mantap, stabil, dan dewasa. Kondisi kepribadian yang demikian sering membuat pendidik melakukan tindakantindakan yang tidak professional, tidak terpuji, bahkan tindakan yang tidak senonoh yang merusak citra dan martabat pendidik. Tidak sedikit pendidik yang mengikut sertakan masalah yang dari luar sekolah ke dalam sekolah, sehingga dalam pelaksanaannya peserta didiklah yang menjadi pelampiasan penyelesaian masalahnya.

Untuk menciptakan kepribadian peserta didik yang disiplin, maka harus dimulai dengan pribadi pendidik yang disiplin, arif, dan berwibawa. Tidak akan menghasilkan peserta didik yang diharapkan apabila pendidiknya sendiri tidak menjadi contoh yang baik bagi peserta didiknya sendiri.

Tidak hanya dua kompetensi tersebut, satu lagi yang menjadi perbincangan adalah kompetensi sosial. Kompetensi sosial terkait kemampuan pendidik sebagai makhluk sosial yang santun, mampu berkomusikasi dan berinteraksi dengan lingkungan secara efektif dan menarik, mempunyai rasa empati terhadap orang lain. 
Menurut peraturan pemerintah nomor 74 tahun 2008, pendidik sekurang-kurangnya harus memiliki kompetensi untuk:

a. Berkomunikasi dengan baik secara lisan maupun tulisan, dan isyarat

b. Menggunakkan teknologikomunikasi dan informasi

c. Bergaul secara efektif dengan peserta didik, sesame pendidik, tenaga kependidikan, orangtua/wali peserta didik.

Sangat diperlukan adanya kompetensi sosial pada pendidik, karena dengan jiwa sosial yang baik, maka penyampaian materi pembelajaran akan mempermudah jalannya proses pemahaman. Dalam pemahaman pembelajaran peserta didik sangat mengharapkan pendidik yang mengajar dengan interaktif, aktif, dan menyenangkan.

Sudah menjadi perbincangan yang hangat bahwa pendidik matematika adalah pendidik yang tegas yang peserta didik anggap bahwa pendidik tersebut adalah menakutkan. Padahal pada kenyataanya tidak ada tujuan seperti itu. Hal tersebut tidak lain karena kompetensi sosialnya masih rendah, dengan niatan tegas justru dianngap menakutkab oleh peserta didiknya. Oleh karena itu pentingnya kompetensi social pada pendidik sangat diperlukan.

\section{Menurunnya Kualitas Proses Dan Hasil Belajar Matematika Peserta didik}

Pendidikan sudah tidak asing lagi di zaman sekarang ini. Bahkan sekarang ini sudah menjadi kewajiban untuk semua anak di Indonesia dalam rangka mencerdaskan kehiduan bangsa. Dalam pelaksanaannya, semakin lama belajar, peserta didik justru jenuh dan bosan dalam belajar sehingga sangat diperlukan pendidik berkualitas dan kompeten yang dapat membuat semangat dan meningkatnya kualitas hasil belajar peserta didik.

Ada banyak faktor psikologis yang dapat mempengaruhi rendahnya hasil belajar peserta didik, antara lain adalah:

a. Minat Belajar

Minat menjadi salah satu hal pentinng dalam mendorong peserta didik dalam meningkatkan hasil belajar peserta didik, karena minat belajar ini bersangkutan dengan keinginan dan kemapuan peserta didik dalam pelajaran yang diinginkannya khususnya pelajaran matematika.

Slameto (2003: 180) mengemukakan bahwa minat merupakan suatu rasa lebih suka dan rasa ketertarikan pada suatu hal atau aktivitas, tanpa ada yang menyuruh. Minat pada 
dasarnya adalah penerimaan akan suatu hubungan antara diri sendiri dengan suatu diluar diri. Semakin kuat atau dekat hubungan tersebut, maka akan semakin besar minat.

b. Motivasi Belajar Peserta Didik

Proses belajar sangat membutuhkan motivasi untuk mendorong hasil belajarnya, karena dalam pebelajaran, peserta didik akan menurun jika tidak punya motivasi untuk menggapai apa yang diinginkannya. Krisis motivasi juga bisa menjadikannya faktor terbesar yang membuat menurunnya hasil belajar peserta didik.

Menurut Irwanto (2010: 39), mendefinisikan bahwa motivasi merupakan pendorong seseorang untuk belajar. Motivasi timbul karena adanya keinginan dalam diri seseorang. Seseorang berhasil dalam belajar karena ia ingin belajar.

c. Perhatian

Perhatian adalah keaktifan peningkatan kesadaran seluruh fungsi jiwa yang dikerahkan dalam pemusatannya kepada barang sesuatu baik yang ada dalam kehidupan maupun yang ada diluar individu .

Selain empat faktor tesebut, masih banyak faktor yang dapat mempengaruhi hasil belaja peserta didik, yaitu faktor dari luar seperti

1) Faktor keluarga

Keluarga bisa dijadikan faktor paling penting dalam hasil belajar peserta didik, seperti keadaan ekonomi keluarga, keadaan ekonomi ini memang sangatlah sensitive karena sudah tidak dipungkiri lagi sekarang ini biaya pendidikan menjadi mahal yang membuat anak- anak rela putus sekolah karena keadaan tersebut, orang tua yang mendidik juga menjadi salah satu masalah dalam pendidikan karena kebiasaan mendidik membuat anak menjadi ketergantungan, relasi antara anggota keluarga, dan suasana rumah. Dapat terlihat jelas jika keadaan rumahnya dalamm keadaan masalah, maka akan berdampak pada peserta didik yang bersangkutan.

a. Faktor lingkungan sekolah

Banyak sekali faktor yang timbul dari faktor lingkungan sekolah, diantaranya adalah:

1) Metode Mengajar

Metode mengajar tidak lepas kaitannya dengan ikut serta pendidik. Biasanya peserta didik sekarang ini pilih-pilih dalam belajar, mana pendidik yang memang 
menyenagkan dan mengesankan baginya dan mana yang tidak. Biasanya pendidik yang menyenangkan dan mengesankan dijadikannya pelajaran favorit. Hal tersebut membuat adanya perbedaan dalam setiap mata pelajaran. Karena sudah diwajibkan untuk semua peserta didik untuk semangat pada semua mata pelajaran dan mengasilkan hasil yang memuaskan.

2) Relasi Pendidik dan Peserta didik

Relasi atau yang kita kenal adalah hubungan sangatlah penting, karena hubungan pendidik dan peserta didik yang baik akan mepengaruh besar pula pada proses belajar mengajar dalam kelas khususnya belajar matemtika. Selain itu, hubungan yang baik ini akan sangat berdampak pada hasil belajar peserta didik.

3) Relasi Peserta didik dengan Peserta didik

Relasi peserta didik dengan peserta didik juga sangat berpengaruh dalam hasil belajar peserta didik, tidak hanya hubungan antara peserta didik dan pendidik. Hubungan ini dikatakan sangat berpengaruh terhadap hasil belajar peserta didik karena biasanya keadaan kondisi sosial antara satu peserta didik dengan peserta didik lain berbeda dan adanya perbedaan diantanya yang membuatnya harus menerima dan menghargai akan adanya pebedaan.

4) Disiplin Sekolah

Memang agak sulit dalam menegakkan kedisiplinan ini, namun dengan segala upaya yang dikerahkan dan tetap semangat dalam menegakkannya, maka kedisiplinan inipun akan tertana sedikit demi sedikit dan timbullah kesadaran pada diri masing-masing.

5) Media Belajar

Media belajar ini biasanya disiapkan oleh pihak sekolah karena dengan adanya, dapat mengembangkan wawasan peserta didik dan tidak terpaku dengan apa yang di berikan oleh pendidik, sehingga dapat meningkatkan hasil belajar peserta didik.

6) Waktu Sekolah

Jika dibandingka dengan Negara-negara lain, waktu belajar di Indonesia agak pendek. Negara maju lainnya memiliki waktu yang sangat panjang dalam 
proses belajar sehingga peserta didiknya sudah terbiasa dengan membaca dan belajar.

\section{Pengembangan Kompetensi Pendidik Matematika}

Kompetensi pendidik merupakan kemampuan seorang pendidik dalam melaksanakan kewajibannya secara tanggungjawab dan layak (Muhammad Nurtanto: 2016). Berdasarkan Peraturan Mentri Pendidikan Nasional Republik Indonesia Nomor 16 Tahun 2007 tentang Standar Kualifikasi Akademik dan Kompetensi Pendidik dikembangkan secara utuh dalam empat kompetensi meliputi kompetensi pedagogik, kompetensi kepribadian, kompetensi sosial dan kompetensi profesional yang diperoleh melalui pendidikan profesi.

Pengembangan kompetensi adalah cara mengidentifikasi kompetensi mengajar. Menurut Cruickshank (1985); (C. Jacob) ada enam cara dalam mengidentifikasi kompetensi mengajar, yaitu (1) dengan mempelajari hasil-hasil penelitian tentang kemampuan mengajar dalam hubungannya dengan prestasi subjek didik; (2) diperoleh dari para pendidik berpengalaman yang dianggap sebagai pakar; (3) disimpulkan dari hasil poll stakeholders pendidikan; (4) diambil dari literatur; (5) diturunkan dari bermacam-macam peranan pengajar; dan (6) sebagai hasil dari analisis tugas mengajar pada tingkat dan bidang kurikulum yang berbeda. Sehingga beberapa upaya untuk mengembangkan empat kompetensi pendidik dalam pembelajaran ialah:

\section{a. Melakukan Penelitian Tindakan Kelas}

Pemanfaatan penelitian merupakan salah satu pendekatan pemecahan berbagai permasalahan yang digunakan dalam rangka peningkatan kualitas pendidikan. Para pendidik tidak lagi hanya sekedar sebagai penerima pembaharuan, melainkan ikut bertanggung jawab dan oleh karena itu berperan aktif untuk mengembangkan pengetahuan dan keterampilannya sendiri melalui penelitian tindakan yang dilakukan terhadap proses pembelajaran yang dikelolanya.

Penelitian tindakan kelas ini dimaksudkan untuk mengatasi suatu permasalahan yang terdapat di dalam kelas, maka pendidiklah yang paling mengetahui kenapa masalah itu muncul. Untuk mengetahui masalah itu muncul, pendidik perlu menjadi peneliti. Peranan pendidik sebagai peneliti tindakan kelas mengandung aspek psikologis dan sosial karena untuk mengamati diri dalam kemampuan profesionalnya mengandung ancaman terhadap 
diri dan karirnya. Bagaimana kalau pengamatan itu menunjukkan gambaran buruk dari penampilan profesinya? Bagaimanakah penghargaan atasan dan kolega tentang hal ini?

Seorang pendidik yang profesional selalu mengembangkan diri untuk memenuhi tuntutan dalam tugasnya sebagai pendidik. Pengembangan diri itu meliputi semua aspek pendidik dalam kemampuannya sebagai pendidik termasuk untuk menentukan dan mengambil keputusan yang sesuai dengan profesinya, dan melakukan penelitian tindakan kelas sebagai salah satu upaya untuk meningkatkan cara mengajar.

Dengan tertumbuhkannya budaya meneliti yang merupakan dampak bawaan dari pelaksanaan PTK secara kesinambungan, maka banyak manfaat yang dapat dipetik yang secara keseluruhan dapat diberi label "Inovasi Pendidikan" karena para pendidik semakin diberdayakan untuk mengambil berbagai prakarsa professional secara semakin mandiri.

\section{b. Pengembangan Professionalisme Pendidik Melalui Leasson Study}

Leasson study pertama keli dikembangkan di Jepang oleh Makoto Yoshida seorang pendidik mata pelajaran Matematika di Sekolah Dasar Jepang ( Japanese Elementary School Matemathic) dan bekerja sama dengan Catherine Lewis seorang ilmuwan senior di Universitas Mills California yang mengembangkan Lesson study di Amerika yang dilaksanakan sebagai program pengembangan professionalisme pendidik (Almira Amir: 2013). Leasson study dipercaya berhasil meningkatkan praktik pembelajaran (Ali Mahmudi: 2009).

Leasson Study adalah model pembinaan dalam profesi pendidikan melalui pengkajian pembelajaran secara kolaboratif dan berkesinambungkan berdasarkan prinsip-prinsip kolegalitas dan mutual learning untuk membangun komunitas belajar. Secara lebih sederhana, tahapan LS dapat dilakukan melalui serangkaian kegiatan: Planning-DoingSeeing (Saito, et al., 2005); (C. Rudy Prihantoro: 101).

Karakteristik dari leasson study adalah peserta didik sebagai inti dari kegiatan pengembangan profesi pendidik dan memberi kesempatan kepada pendidik untuk dengan cermat meneliti proses pembelajaran serta pemahaman peserta didik dengan mengamati dan mendiskusikan praktik pembelajaran di kelas, serta pendidik secara aktif terlibat dalam proses perubahan pembelajaran dan pengembangan kurikulum.

Model leasson study banyak mendapat perhatian oleh kalangan pendidik karena memiliki nilai strategis dalam mengembangan profesionalisme pendidik dan dapat 
meningkatkan kinerja dan keprofesionalannya yang akhirnya dapat meningkat mutu pembelajaran dan menghasilkan peserta didik berkualitas tinggi.

\section{c. Melakukan Pembinaan Pendidik Secara Terus-Menerus}

Salah satu komponen yang paling utama didunia pendidikan adalah pendidik dan dalam konteks pendidikan mempunyai peranan yang besar dan strategis karena disebabkan pendidiklah yang berada dibarisan terdepan dalam pelaksanaan pendidikan. Pendidik mempunyai misi dan tugas yang berat, namun mulia mengantarkan tunas-tunas bangsa ke puncak cita-cita. Oleh sebab itu, selayaknya pendidik sudah mempunyai berbagai kompetensi yang berkaitan dengan tugas dan tanggung jawab.

Pembinaan merupakan suatu upaya yang dilakukan untuk membuat sesuatu menjadi lebih baik. Hal ini sesuai dengan pendapat Thoha (2003: 7); (Sri Silvia: 2013) yang mendefinisakan "pembinaan adalah suatu proses kegiatan menuju ke arah yang lebih baik dalam hal perubahan, kemajuan, peningkatan, pertumbuhan, evaluasi dan berbagai kemungkinan atas sesuatu".

Menurut Imron (1995: 5); (Sri Silvia: 2013) mengemukakan secara terminologis, “ pembinaan pendidik sering diartikan sebagai serangkaian usaha bantuan kepada pendidik terutama bantuan yang berwujud layanan profesional yang dilakukan kepala sekolah dan pengawas serta pembina lainnya untuk meningkatkan proses dan hasil belajar".

Pembinaan terhadap pendidik dilakukan secara terus-menerus untuk mengembangkan kemampuan professionalisme yang telah dimiliki oleh pendidik dan diharapkan terjadi peningkatan dalam menjalankan profesinya.

\section{d. Melakukan Pemberdayaan Musyawarah Pendidik Mata Pelajaran (MGMP)}

Musyawarah pendidik mata pelajaran adalah salah satu program pengembangan kompetensi pendidik yang cukup efektif bagi peningkatan kualitas pendidik mengelola pembelajaran sehingga menjadi tenaga pengajar yang professioanal.

Langkah ini dapat dilakukan pendidik yang berperan sebagai fasilitator agar mampu mengefektifkan program musyawarah pendidik mata pelajaran di sekolah demi mengasah kemampuan pendidik ke arah yang lebih baik (Hadawi Nawawi: 1994); (Samsuardi: 2014).

Musyawarah pendidik mata pelajaran diperlukan sebagai wahana diskusi, komunikasi dan informasi bagi pendidik dalam memecahkan berbagai masalah pembelajaran peserta 
didik serta sebagai wadah pertemuan pendidik untuk mengubah paradigma pembelajaran dari pola pikir behavioristic ke konstruktivistik sesuai dengan kurikulum (Hujono: 2001); (Samsuardi: 2014).

\section{e. Memotivasi Pendidik Mengikuti Kursus Kependidikan}

Tujuan dari kursus kependidikan adalah untuk meningkatkan kompetensi pendagogik dengan spesialisasi keahliannya masing-masing bidang ke arah yang lebih baik. Misalnya kursus keterampilan berbasis kecakapan hidup (life skill) seperti kursus computer, bahasa asing, SPSS untuk memudahkan pendidik dalam melakukan penilaian bagi peserta didik, maupun kursus sesuai dengan konsentrasi masing-masing yang dianggap penting dan untuk mengembangkan kompetensi pendidik di dunia pendidikan.

\section{f. Program Sertifikasi}

Sertifikasi adalah proses uji kompetensi yang dirancang untuk mengungkapkan penguasaan kompetensi seseorang sebagai landasan pemberian sertifikat pendidik (Mulyasa: 2007); (Hesti Murwati: 2013).

Wibowo (2004); (Hesti Murwati; 2013), mengungkapkan bahwa sertifikasi pendidik bertujuan untuk melindungi profesi pendidik, melindungi masyarakat dari praktek-praktek yang tidak kompeten, membantu dan melindungi lembaga penyelenggara pendidikan, membantu citra masyarakat terhadap profesi pendidik dan memberikan solusi dalam rangka meningkatkan mutu pendidk dan tenaga kependidikan.

Pendidik yang telah lulus program sertifikasi profesi akan mendapatkan sertifikat pendidik yang merupakan bukti bahwa pendidik telah memenuhi standar kualifikasi dan kompetensi sebagai seorang pendidik. Dengan adanya pemberian sertifikasi maka akan meningkatkan motivasi kerja pendidik dan kualitas kompetensi pendidik.

\section{g. Mengadakan Lokakarya (Workshop)}

Kemampuan pendidik saat melaksanakan dan mengelola pembelajaran perlu ditingkatkan yaitu memaksimalkan pembelajaran aktif dan menjadi fokus dalam peningkatan mutu pendidik dikarenakan oleh alasan bahwa dengan diterapkannya pembelajaran yang aktif dapat memudahkan peserta didik untuk menggunakan potensi saat belajar (Abdul Muin Sibuea: 2014).

Untuk meningkatkan kemampuan pendidik maka mengadakan lokakarya (workshop) khususnya workshop tentang kependidikan yang merupakan kegiatan belajar kelompok 
yang terdiri dari petugas-petugas pendidikan yang memecahkan problema yang dihadapi melalui percakapan dan bekerja secara kelompok maupun bersifat perorangan, masalah yang dibahas muncul dari peserta sendiri, metode pemecahan masalah dengan musyawarah dan penyelidikan (Samsuardi: 2014).

\section{h. Pelaksanaan Supervisi Kepala Sekolah}

Supervisi merupakan usaha memberikan layanan kepada pendidik-pendidik baik secara individual maupun kelompok dalam usaha memperbaiki pengajaran dalam peningkatan mutu pendidikan. Sebagi supervisior, kepala sekolah diharuskan melakukan upaya pengawasan serta pengarahan bagi pendidik untuk dapat meningkatkan profesionalitasnya dalam mengajar di sekolah. Sehubungan dengan hal ini, ada beberapa hal yang menjadi tujuan dari supervisi yang ingin dicapai antara lain adalah sebagai berikut:

1) Membantu pendidik memahami tujuan-tujuan pendidikan dan berupaya untuk mewujudkan pendidik mencapai tujuan tersebut.

2) Membantu pendidik dalam memahami secara jelas kebutuhan peserta didik di sekolah maupun dalam masyarakat dengan tujuan untuk membimbingnya dalam pengalaman belajar peserta didik.

3) Ikut meningkatkan kecakapan pendidik menggunakan model belajar untuk meningkatkan minat belajar peserta didik.

4) Mengarahkan pendidik untuk memahami penggunaan alat peraga pelajaran, metodemetode, dan supervisi.

5) Mengarahkan pendidik untuk menata administrasi kelas dan kemampuan dalam menilai kemampuan peserta didik dari hasil pembelajaran itu sendiri.

Setiap pelaksanaan program pendidikan memerlukan adanya supervisi atau disebut juga dengan pengawasan. Oleh karenanya supervisi kepala sekolah menjadi sesuatu hal yang penting dalam pengembangan kemampuan pendidik mengelola situasi belajarmengajar agar memperoleh kondisi yang lebih baik (M. Ngalim Purwanto: 2004); (Samsuardi: 2014).

\section{i. Mengadakan Rapat Sekolah}

Rapat sekolah merupakan pertemuan yang cukup penting untuk mendiskusikan berbagai hal, termasuk memecahkan masalah yang dihadapi pendidik untuk meningkatkan 
kemampuan dalam mengajar. Dilakukan rapat dalam rangka untuk meningkatkan kualitas pendidik dalam mengemban tugas dan tanggungjawab. Salah satu bentuk rapat pendidik yang dilaksanakan oleh kepala sekolah adalah konferensi atau musyawarah untuk membimbing pendidik untuk lebih efektif dalam mengajar.

Maka mengacu pada tujuan di atas, maka keberhasilan rapat pendidik merupakan tanggungjawab bersama dan peranan supervisior sebagai pemimpin sangat besar bahkan sangat menentukan sampai dimana anggotanya berpartisipasi.

\section{Meningkatkan Kualitas Proses dan Hasil Pembelajaran Matematika Peserta didik}

\section{a. Mutu Pembelajaran}

Belajar adalah suatu proses yang ditandai dengan adanya perubahan pada diri seseorang. Hal sesuai dengan pendapat Woolfolk dan Nicholich (1984: 159); (Putro Eko: 2) yang menyatakan bahwa "Learning is a change in a person that comes about as a result of experience".

Mutu pembelajaran pada dasarya merupakan sasaran utama dari setiap penyelenggaraan pendidikan dan perpaduan antara proses dan hasil belajar yang dicapai peserta didik dengan dukungan pendidik dan tenaga pendidikan lainnya untuk merefleksikan keberhasilan sekolah dalam mencapai tujuan pembelajaran.

Pembelajaran dikatakan bermutu jika semua unsur termasuk peserta didik, pendidik dan tenaga kependidikan mampu menunjukkan kinerja terbaiknya dalam melaksanakan tugas dan tanggungjawabnya. Dalam sudut pandang lain, mutu pembelajaran dapat dilihat berdasarkan kualitas input (masukan), proses dan output (hasil) yang dicapai. Dengan mutu pembelajaran yang berkualitas maka akan meningkatkan proses dan hasil belajar peserta didik khususnya dibidang matematika.

\section{b. Reformasi Pembelajaran}

Reformasi pembelajaran pada hakikatnya ingin memperbaiki cara-cara belajar di sekolah atau di mana pun agar anak-anak didik kita lebih cerdas, kreatif, kritis, dan bijaksana dalam berpikir dan bertindak, daripada anak-anak didik yang dihasilkan oleh sekolah-sekolah konvensional.

Pemerintah telah melakukan reformasi pendidikan sejak pemerintahan kabinet Indonesia Bersatu yang pertama antara lain melalui pembiayaan pendidikan, perbukuan dan sistem perencanaan (Kemendiknas: 2010). 
Misi dari reformasi ini adalah 5K yaitu (Ketersediaan, Keterjangkauan, Kualitas dan

Relevansi, Kesetaraan dan Kepastian). Tujuan dari reformasi untuk menghasilkan suatu sistem yang dapat mendukung tercapainya efisiensi nasional dalam bidang pendidikan.

Ada dua aspek penting dalam reformasi pembelajaran yakni

a. Pembaruan pendekatan pembelajaran yang menyangkut esensi, materi dan metode pembelajaran.

b. Pemanfaatan teknologi, informasi dan komunikasi untuk menunjang keberhasilan dalam strategi pembelajaran (Ace Suryadi: 2007).

Maka dua aspek ini harus dilakukan untuk bisa tercapainya reformasi pendidikan yang lebih berkualitas dan meningkatkan mutu pendidikan di Indonesia khususnya untuk meningkatkan hasil dan proses belajar peserta didik dalam pelajaran matematika.

\section{c. Pemanfaatan Imu Teknologi dalam Pembelajaran Matematika}

Kemajuan ilmu teknologi telah mendorong terjadinya banyak perubahan termasuk dalam bidang pendidikan dan meningkatkan efisiensi dan efektivitas pada setiap kegiatannya (Budi Murtiyasa: 3).

Banyak institusi pendidikan khususnya di luar negeri misalnya Malaysia, berusaha meningkatkan kualitas pembelajarannya dengan memanfaatkan kemajuan TIK melalui program e-learning.

Dengan e-learning, pembelajaran matematika lebih efektif dan efisien untuk mencapai daya matematika. E-learning memberikan manfaat diantaranya fleksibilitas program, bahan pembelajaran dapat dibuat lebih menarik juga berkesan dan meningkatkan kualitas pembelajaran matematika.

\section{d. Pembaruan Pendekatan Pembelajaran}

Upaya pembaruan dengan maksud memperbaiki pendidikan matematika terutama dari pembelajaran. Tolak ukur sesungguhnya dari sistem pendidikan adalah seberapa besar mampu membangkitkan gairah belajar secara menyenangkan terutama pelajaran matematika.(R. Soedjadi: 2007).

Dryden dan Vos (2003) menyimpulkan dari hasil penelitian dan observasi mereka di seluruh dunia bahwa dalam setiap sistem pendidikan yang terbukti berhasil, citra diri ternyata lebih penting dari pada materi pelajaran. Dengan pendekatan inilah setiap peserta 
didik akan terdorong untuk membangun citra diri yang sangat penting bagi pertumbuhan dan perkembangan mereka dalam proses pembelajaran terutama pembelajran matematika.

\section{e. Motivasi Pendidik dalam Rangka Peningkatan Mutu Pembelajaran}

Motivasi pendidik merupakan kekuatan internal yang ada dalam diri sehingga mempunyai keinginan dan semangat yang kuat untuk berusaha seoptimal mungkin sehingga mencapai keberhasilan dalam melaksankan peran sebagai pendidik dan sebagai faktor individual yang mendasari perilaku untuk melakukan upaya dalam mencapai tujuan.

Motivasi dapat diwujudkan melalui intensitas usaha dan kesediaan melaksanakan aktivitas sebagai tuntutan pekerjaan dan motivasi yang tinggi akan mendorong pendidik untuk memberikan perhatian, mengarahkan kemampuan dalam melaksanakan upaya sesuai dengan perannya sebagai pendidik sehingga terjadi peningkatan mutu atau keberhasilan dalam pembelajaran peserta didik (Edi Suhaedi, dkk: 2014).

\section{f. Meningkatkan Komunikasi Matematika}

Komunikasi merupakan salah satu hal terpenting dalam proses pembelajaran, ide-ide yang muncul beserta pemahaman dikarenakan komunikasi yang baik. Komunikasi matematika mempunyai relasi yang penting terhadap pemahaman matematika.

Untuk mendeskripsikan pemahaman terhadap kemampuan komunikasi matematik, setidaknya dapat dijadikan acuan beberapa hal berikut pertama, tujuan komunikasi matematik (Mohammad Aufin: 2012).

Matematika sebagai bahasa simbol dan bersifat universal dan dapat dipahami setiap orang kapan dan dimana saja. Pengembangan bahasa dan simbol dalam matematika itu bertujuan untuk mengkomunikasikan matematika, agar peserta didik dapat merefleksikan dan menjelaskan pemikiran peserta didik mengenai ide dan hubungan matematika.

Baroody (1993); (Mohammad Aufin: 2012) mengemukakan ada lima aspek dalam komunikasi matematik, yaitu; (1) aspek representasi (2) aspek mendengar (3) aspek membaca (3) aspek disukusi dan (5) aspek menulis.

Komunikasi peserta didik dapat diketahui setelah pemberian skor dalam menjawab soal , pemberian skor kemampuan komunikasi peserta didik didasarkan pada efektifitas, ketepatan dan ketelitian. Maka dari lima aspek komunikasi matematik perlu ditingkatkan untuk memudahkan dalam pemahaman matematika. 


\section{g. Gaya Belajar yang Efektif}

Gaya belajar adalah suatu cara yang ditempuh oleh seorang peserta didik untuk memproses informasi dalam pembelajaran. Gaya belajar peserta didik erat kaitannya dalam penyerapan informasi. Cara peserta didik menyerap informasi ini dinamakan modalitas belajar. DePotter (2001:85) mengelompokkan modalitas belajar menjadi tiga, yaitu modalitas visual, modalitas auditori, dan modalitas kinekstetik.

Peserta didik yang memiliki gaya belajar visual melakukan pembelajaran dengan mengobservasi dan gambar. Peserta didik yang tergolong dengan modalitas ini cenderung suka melihat gambar dan diagram, menyaksikan suatu presentasi maupun video. Peserta didik dengan gaya belajar auditori malakukan pembelajaran dengan berdiskusi dan mendengarkan. Peserta didik dengan modalitas ini lebih suka mendengarkan musik, ceramah, diskusi, debat dan instruksi verbal. Peserta didik dengan gaya belajar kinestetik melakukan pembelajaran dengan bergerak dan bekerja. Peserta didik yang tergolong dengan modalitas ini cenderung suka "menangani", bergerak, menyentuh, merasakan dan mengalami sendiri.

Kombinasi ketiga modalitas ini akan mempercepat peserta didik memahami materi. Peserta didik menyimpan memori visual, auditori dan kinestetik dalam bagian-bagian otak yang berbeda. Oleh karena itu, cara multi sensori ini dalam belajar mungkin adalah cara yang efektif.

Gaya belajar dari tiga modalitas ini pernah dilakukan penelitian oleh Hafiz Faturohman di MTs Negeri 32 Jakarta. Berdasarkan hasil penelitiannya tesebut beliau mengatakan peningkatan yang terjadi dan hasil kemampuan pemecahan masalah yang diperoleh peserta didik, dapat disimpulkan bahwa penerapan pendekatan dengan modalitas visual, auditori dan kinekstetik dapat meningkatkan kemampuan pemecahan masalah matematika peserta didik.

\section{KESIMPULAN}

Pendidikan harus mendapatkan perhatian serius karena dengan pendidikan akan terlihat maju mundurnya sumber daya manusia, karena kualitas sumber daya manusia dipengaruhi dengan meningkatnya kualitas pendidikan dan pendidik. Tentu saja pendidikan Indonesia tidak mau terbelakang akibat munculnya problematika yang terjadi di lapangan. 
Problematika yang banyak muncul akan menghambat proses pembelajaran dan sistem pencerdasan peserta didik. Berbagai persoalan pembelajaran yang menyangkut pada pembelajaran matematika perlu dicari jalan tengah yang terbaik sebagai solusinya. Upaya yang dapat dilakukan untuk mengatasi problematika pendidikan pada pelajaran matematika diantaranya melakukan penelitian tindakan kelas, pengembangan professionalisme pendidik melalui leasson study, melakukan pembinaan pendidik secara terus-menerus, melakukan pemberdayaan musyawarah pendidik mata pelajaran (MGMP), memotivasi pendidik mengikuti kursus kependidikan, program sertifikasi, mengadakan lokakarya (workshop), pelaksanaan supervisi kepala sekolah, mengadakan rapat sekolah, mutu pembelajaran, reformasi pembelajaran, pemanfaatan ilmu tekonologi, pembaruan pendekatan pembelajaran, melakukan penelitian tindakan kelas, gaya belajar yang efektif dan meningkatkan pemahaman tentang komunikasi matematika.

Untuk itu perlu kesadaran dan usaha bersama agar dalam pembelajaran matematika tidak kering tanpa konteks, namun pembelajaran matematika harus disertai dengan ruh matematika itu sendiri.

\section{REFFERENSI}

Amir, A. (2013). Pengembangan Profesionalisme Guru dalam Pembelajaran Melalui Leasson Study. Jurnal Logaritma, 133.

Aufin, M. (2012). Komunikasi dan Pemecahan Masalah dalam Pembelajaran Matematika. Jurnal Psikologi, 99.

Faturohman, H. (2015). Peningkatan Kemampuan Pemecahan Masalah Matematika Peserta Didik dengan Penerapan Pendekatan Visual, Auditori dan Kinestetik. Jurnal Pendidikan Matematika dan Matematika, 60.

Hasratudin. (2008). Permasalahan Pembelajaran Matematika Sekolah dan Alternatif Pemecahannya. Jurnal Phytagoras, 67-68.

Hidayah, N. (2017). Bahan Ajar Sistem Remunirasi. 8.

Indriani, F. (2015). Kompetensi Pendagogik Guru dalam Mengelola Pembelajaran IPA di SD dan MI. Jurnal Fenomena, 19.

Jacob, C. (n.d.). Pengembangan Kompetensi Menuju Guru Matematika Profesional . 6.

Mahmudi, A. (2009). Mengembangkan Kompetensi Guru Melalui Leasson Study. Jurnal Forum Kependidikan, 84. 
Mane, A., \& Surdin. (2016). Faktor-Faktor Penyebab Rendahnya Hasil Belajar Siswa pada Mata Pelajaran Geografi di SMA Negeri 1 Mawasangka. Jurnal Penelitian Pendidikan Geografi, 422-423.

Marsigit. (2008). Pengembangan Kompetensi Guru Matematika Melalui Model-Model Pembelajaran, Leasson Study dan PTK Melalui Peningkatan Peran MGMP. 1.

Murwati, H. (2013). Pengaruh Sertifikasi Profesi Guru terhadap Motivasi Kerja dan Kinerja Guru di SMK Negeri Se-Surakarta. Jurnal Pendidikan Bisns dan Ekonomi, 14.

Nurtanto, M. (2016). Mengembangkan Kompetensi Profesionalisme Guru dalam Menyiapkan Pembelajaran yang Bermutu. 554.

Prihantoro, C. R. (n.d.). Pengembangan Profesionalisme Guru Melalui Model Leasson Study. 101.

Samsuardi. (2010). Menajemen Pengembangan Sumber Daya Guru pada Lembaga Pendidikan Madrasah.

Sapan, A., Darwis, M., \& Minggi, I. (2017). Analysis on Math Teacher Competence SMK Pelayaran in Makassar. Jurnal Daya Matematis, 85-94.

Sibuea, A. M. (2014). Supervisi Akademik Teknik Workshop Meningkatkan Kemampuan Guru Melaksanakan Pembelajaran yang Aktif. Jurnal Manajemen Pendidikan Indonesia, 67.

Silvia, S. (2013). Persepsi Guru Terhadap Pembinaan Kompetensi Profesional Guru oleh Kepala Sekolah di SMP Negeri 18 Padang. Jurnal Administrasi Pendidikan, 427-461.

Suhaedi, E., Mujahidin, E., Bahrudin, E., \& Tafsir , A. (2014). Pengembangan Motivasi dan Kompetensi Guru dalam Peningkatan Mutu Pembelajaran di Madrasah. International Journal of Islamic Education, 48.

Suryadi, A. (2007). Pemanfaatan ICT dalam Pembelajaran. Jurnal Pendidikan Terbuka dan Jarak Jauh, 86.

Wibowo, C. H. (2015). Problematika Profesi Guru dan Solusinya Bagi Peningkatan Kualitas Pendidikan di MTs. Negeri Nguntoronadi Kabupaten Wonogiri.

Widoyoko, E. P. (n.d.). Evaluasi Program Pembelajaran. 2.

Yanto, N., Fatchiya, A., \& Anwas, O. M. (2017). Analisis Kompetensi Pendagogik dan Profesional Guru Matematika SMA Negeri di Kabupaten Kuantan Singingi, Riau. Jurnal Majalah Ilmiah Universitas Al-Muslim, 41. 